\title{
Effect of Tannin and Flavonoids of Different Sources on Ruminal Fermentation and Microbial Populations in Small Tail Han Rams
}

Walaa I. Mohamaden ${ }^{*}$, Ibrahim M. Hegab ${ }^{2}$, Chen Hui ${ }^{3}$, Shi Shang-li ${ }^{3}$

${ }^{1}$ Department of Animal Medicine, Faculty of Veterinary Medicine, Suez Canal University, Ismailia 41522, Egypt.

${ }^{2}$ Department of Hygiene, Zoonosis and Animal Behavior \& Management Faculty of Veterinary Medicine, Suez Canal University, Ismailia 41522,Egypt.ibrahim_hegab@vet.suez.edu.eg.

${ }^{3}$ Key Laboratory of Grassland Ecosystem of the Chinese Ministry of

Education, College of Grassland science, Gansu Agricultural University, Lanzhou 730070, China.

*Corresponding authors : walaa_mohamedien@vet.suez.edu.eg and shishl@gsau.edu.cn

\begin{abstract}
Plant secondary metabolites (PSM $\mid)$ are used as livestock feed additives instead of chemicals for their multiple effects on rumen microbiota, ammonia $\mathrm{N}$ production and fermentation end products. In this study we investigated the effect of two kinds of PSM used as feed additives and compare their effects to the effect of alfalfa varieties which contain PMS in different concentrations. Fifteen small tail Han rams were randomly allocated into five groups $(n=3 /$ group). CONT group (control group fed on basal diet), HT group (basal diet supplemented with $2 \mathrm{~g}$ of Hydrolizable tannin), PF group (basal diet supplemented with $2 \mathrm{~g}$ of Pueraria flavone) G3 group (basal diet $+200 \mathrm{~g}$ of Gannon No. 3 alfalfa) and G9 group (basal diet $+200 \mathrm{~g}$ of Gannon No. 9 alfalfa) for 30 days. At the end of the experiment rumen samples were collected for rumen $\mathrm{pH}$, ammonia nitrogen concentration, total and proportional volatile fatty acids (VFA) and PCR quantification of total bacteria, $F$. succinogenase, methanogens and protozoa population. An in situ ruminal digestion kinetics experiment for soybean NDF was applied. Results showed that ruminal $\mathrm{pH}$ and ruminal ammonia $\mathrm{N}$ were not influenced by any of different diets, but total volatile fatty acids (TVFA) and molar proportion of acetic acid were significantly reduced in HT group and significantly increased in G3 group. Protozoa were
\end{abstract}


significantly increased in G9 and PF groups. It could be concluded feeding on Gannon No. 3 variety could be used for dairy ewes and those causing decrease in rumen protozoa numbers could be used for fattening rams. Feed additives and different varieties of alfalfa could be used in different feeding managements to obtain the maximum production

Keywords: rumen, hydrolizable tannin, Peuraria flavone, alfalfa, sheep.

\section{Introduction}

Rumen is the most important digestive organ in ruminants; it plays a key role in the digestion of cellulose and plant fibers through fermentation processes. Rumen environment encloses mainly bacteria and protozoa which are involved in the process of microbial fermentation. It is a process that manipulates rumen metabolism, ruminal digestion, and nutrients availability which, in turn, maintains ruminants' health and productivity (McCann et al., 2014).

Rumen protozoa produce microbiota balance in the rumen as they compete with bacteria and fungi for nutrients as far as they can predate on bacterial and fungal spores (Williams and Coleman 1992). furthermore, protozoa scavenge the oxygen in the rumen to maintain the anaerobic conditions which favor the growth of anaerobic bacteria and fungi (Mosoni et al., 2011). In addition, they produce $\mathrm{H}_{2}$ which is converted into methane $\left(\mathrm{CH}_{4}\right)$ by methanogens
(Morgavi et al., 2014, Belanche et al., 2014). In spite, several studies suggested that defuanation (Complete removal of rumen protozoa) would reduce $\mathrm{CH}_{4}$ emissions and enhance a proper fermentation process in the rumen (Faichney et al., 1999).

Ruminal digestion is affected directly and indirectly by food ingredients. Plants produce secondary metabolites which are biologically active compounds that can affect some animal metabolic processes and growth rate of some microorganis ms (Kamra et al., 2012). Multiple defuanation experiments were established on the concept of adding anti-microbial elements to ruminants' diet (Machmuller et al., 2003; Yáñez-Ruiz et al., 2007 and Li et al., 2018). Some of them used phenols which represent a great category of plant secondary metabolites (PSM) which are characterized by having a profound effect on rumen fermentation because of its known antimicrobial activity against bacteria, protozoa and fungi (Burt, 2004). Phenolic 
compounds are divided into different classes according to their chemical structure or their metabolic pathway. Two classes are the main concerns that attract the attention towards their effect on rumen fermentation and on serum metabolites; hydrolyzable tannin which is derived from gallic and e- gallic acids. The other main class of phenols is the flavonoids which are polyphenolic compounds that include condensed tannin. Flavonoids provide the attractive color to flowers and besides their antimicrobial properties, tannins and flavonoids are reported to reduce the volatile fatty acids (VFA) production or to induce some changes in their proportions, decrease in both rumen ammonia and methane concentration (Tan et al., 2011; Bodas et al., 2012 and Oskoueian et al., 2013). PSM are thought to have an inhibitory effect on the growth of cellulotic and proteolytic bacteria of the rumen by binding with their cell membrane, which in turn influence the degradation of substrates and feed digestibility in rumen (Bodas $\boldsymbol{e t}$ al., 2012). Tannin can reduce the protein degradation in the rumen and the plant cell wall digestion (MacSweeny et al., 2001).
Alfalfa is considered as one of the highest quality forages all over the world. It is of a significant value in the diary managemental systems, and it is recorded to significantly increase the weight, and feed conversion ratio in growing lambs (Alhidary et al., 2016). Alfalfa contains tannins and flavonoids as secondary metabolites which are variable in its amount according to the varieties of alfalfa (McMahon et al., 2000). Alfalfa flavonoid extract (AFE) showed variable effects on the microbial population of rumen of cows whereas

Ruminococcus flavefaciens relative expression tended to decrease with increasing the dose of AFE supplementation, while Butyrivibrio fibrisolvens relative expression tend to increase (Zhan et al., 2017). Feeding ram lambs on purple prairie clover containing high levels of tannin resulted in lower levels of rumen ammonia, total VFA and protozoa (Peng et al., 2016) while other fermentation parameters were not changed.

It is assumed that feeding sheep on different types of PSM or feeding them on the same source with different levels of PMS would provide different effects on rumen protozoal and bacterial activity which will be reflected on the rumen fermentation, digestion. The aim 
of this study was to assess the effect of feeding sheep on two kinds of alfalfa varieties (Gannon No. 3 and Gannon No. 9) which both are possessing different levels of tannin and flavonoids on rumen fermentation, microbial population, fiber digestion and compare to the effect to hydrolyzable tannin and flavonoids of plant extract which are used as feed additives.

\section{Materials and methods}

\section{Diet}

Basal diet contents and its chemical composition are listed in table 1.A clean water was offered ad libtum.

2 Animals and experimental design

Fifteen small tail Han ruminally cannulated rams $(38.24 \pm 1.03$ $\mathrm{Kg}$, aged between15- 18 months, were divided into five groups and housed in a separate pen; control group (CONT) was fed on basal diet, HT group was supplemented with $2 \mathrm{~g}$ of hydrolysable tannins /animal (hydrolysable tannin was extracted from gallnut; content of tannins was greater than 92\%) (Aowei Science and Technology LTD, Zhangjiajie, Hunan, China), PF group was supplemented with $2 \mathrm{~g}$ of Puerariae flavones /animal) Puerariae flavone was extracted from Puerariae Lobota with purity of $81.5 \%$ (Baoji F.S. biological development Co., LTD. China), G3 group offered dried alfalfa Gannon No. 3 (200 $\mathrm{g}$ of / animal) and G9 group offered dried alfalfa Gannon No. 9 (200 g of / a nimal). Both alfalfa varieties were offered in the morning before the usual diet. The experiment extended for 30 days and on day 30 samples were collected. All procedures concerning the animals were following the guidelines of animal care and welfare of Gansu Agricultural University Institutional Animal Care and Use Committee.

\section{In-situ experiment}

Nylon bags of pore size $38-40$ $\mu \mathrm{m}$ and internal dimensions 80 $\times 150 \mathrm{~mm}$ purchased from First Beef Cattle Information and Technology Research Center, Beijing, China were filled with five-grams dried soybean (2$\mathrm{mm}$ screen) were sealed and placed in the rumen of the cannulated rams following the routine all in gradually out at specific time points $(2,4,8,12$ and $24 \mathrm{hrs}$ ). After removal of the bags outside the rumen, they were washed immediately by tap water and stored at $-20{ }^{\circ} \mathrm{C}$. Two bags were not placed in the rumen to be used as $0 \mathrm{hr}$ value. Drying in oven at $103{ }^{\circ} \mathrm{C}$ for 4 hrs. The neutral detergent fiber (NDF) was measured according to Van Soest et al. (1991). For calculation of NDF effective 
degradation $\left(\mathrm{ED}_{\mathrm{NDF}}\right)$ that equation was followed: $\mathrm{ED}_{\mathrm{NDF}}=$ $\mathrm{B}_{\mathrm{NDF}}[\mathrm{KdB} /(\mathrm{KdB}+\mathrm{KpB})]$

$B$ NDF was the potentially degradable fraction of NDF, $\mathrm{KdB}$ was the degradation rate of degradable $\mathrm{B}$ fraction, and $\mathrm{KpB}$ was the passage rate of degradable $\mathrm{B}$ fraction which was assumed $=0.06 / \mathrm{h}$. The disappearance percentage (Y \%) for NDF was calculated according to the following equation described by Ørskov \& McDonald (1979) $\mathrm{Y}_{\mathrm{NDF}}=\mathrm{B}(1-$ $\left.\mathrm{e}^{-(\mathrm{kd} * \mathrm{t})}\right) \quad$ where: $\mathrm{Y}$ is the percentage NDF disappearance at time (t) and $\mathrm{kd}$ is the degradation rate.

4 Rumen fermentation parameters.

Samples of rumen fluid were collected, and the rumen $\mathrm{pH}$ of the ruminal contents was measured immediately using a $\mathrm{pH}$ meter (Model PHS-3C, Hangzhou Aolilong instrument Co, Ltd, China). A $10-\mathrm{ml}$ sample of the strained fluid was collected, acidified with $2 \mathrm{ml} 25$ (\% (w/v) metaphosphoric acid, and stored at $-20{ }^{\circ} \mathrm{C}$ for further analysis of total and proportional VFA and NH3-N. TVFA were assayed according to Matsui et al (1992) by gas chromatography (GC) using methyl valerate as the internal standard in an Agilent 6890 series GC equipped with a capillary column (Agilent Technologies, 6890N network gc system diameter and $1 \mathrm{ml}$ thickness). Ammonia-N was assessed by the colorimetric method described by Weatherburn (1967).

5. DNA extraction and $q P C R$ analysis

Ruminal fluid was collected though the cannula and stored in $-20{ }^{\circ} \mathrm{C}$. Samples were thawed on ice and $200 \mu \mathrm{L}$ aliquots were transferred to centrifuge tubes, and total DNA was extracted from ruminal microbes ( $\mathrm{Yu}$ and Morrison 2004) using a genome extraction kit (TIANamp Stool DNA $^{\circledR} \quad$ Kit $\quad$ (DP328)

TIANGEN Biotechnology Co. Ltd., Beijing, China), according to the manufacturer's instructions. Total DNA purity and concentration were measured using a DHS NanoPro $2010^{\circledR}$ spectrophotometer (DHS Technologies, Inc. Beijing, China.). Total bacteria, methanogens, Fibrobacter succinogenes ( $F$. succinogenes) and total protozoa PCR primers are presented in table 2 (Sangong Engineering Co Ltd., Shanghai, China).

Conventional PCRs for the validation of the specificity of the primers against target genes were performed in $20 \mu \mathrm{l}$ reactions using Premix $\mathrm{Taq}^{\mathrm{TM}}$ DNA Polymerase ${ }^{\circledR} \quad($ TaKaRa $\mathrm{Taq}^{\mathrm{TM}}$ Version 2.0, cat. RR901). Reactions were performed using a Veriti Thermal $\mathrm{Cycler}^{\circledR}$ (Applied Biosystems, Foster 
City, CA, USA) for each gene under the following cycling conditions: one cycle at $95^{\circ} \mathrm{C}$ for $5 \mathrm{~min}$ for initial denaturation followed by 40 cycles of $95^{\circ} \mathrm{C}$ for $30 \mathrm{~s}, 60^{\circ} \mathrm{C}$ for $30 \mathrm{~s}$ and $72^{\circ} \mathrm{C}$ for $1 \mathrm{~min}$, and a final elongation step of $72^{\circ} \mathrm{C}$ for $10 \mathrm{~min}$. The PCR products were analyzed by running on $1 \%$ agarose gels containing ethidium bromide (GoldV iew ${ }^{\circledR}$ ) and visualizing for a single specific band and the absence of primer dimer products.

The corresponding band of agarose gel for each gene was excised and the PCR products for each gene were purified by gel extraction (AxyPrep DNA gel extraction $\left.\mathrm{kit}^{\circledR}\right)$. The PCR products for each gene were then ligated onto the vector (BIOTOPO KAN, Biogen Science Co. Ltd, Hangzhou, China $\left.{ }^{\circledR}\right)$. The recombinant plasmids were extracted using a plasmid mini kit (AxyPrep Plasmid Miniprep kit( $)$ according to the manufacturer's instructions and were quantified by a DHS NanoPro $2010^{\circledR}$. The standard curves for each microbe were generated with $10^{3}$ to $10^{7}$ copies of recombinant plasmids per $\mu \mathrm{L}$.

The qPCR was performed using Trans Start Tip Green qPCR SuperMix kit (TransGen Biotech, Co., Ltd, Beijing, China) by thermal cycler qPCR detection system (Light cycler
$96^{\circledR}$ Roch), and genomic DNA as the template. Each reaction comprised SYBR Green Supermix $(10 \mu L)$, genomic DNA $(5 \mu \mathrm{L}), 0.2 \mu \mathrm{M}$ forward primer $(0.4 \mu \mathrm{L})$, and $0.2 \mu \mathrm{M}$ reverse primer $(0.4 \mu \mathrm{L})$ and PCR grade water $(4.2 \mu \mathrm{L})$ up to $20 \mu \mathrm{L}$ reaction volume. The reaction settings for DNA amplification were as follows; one pre-incubation cycle at $50^{\circ} \mathrm{C}$ for $2 \mathrm{~min}$, one preincubation cycle at $95^{\circ} \mathrm{C}$ for 2 min followed by 40 cycles at $95^{\circ} \mathrm{C}$ for $15 \mathrm{~s}$ and $60^{\circ} \mathrm{C}$ for 1 min. All samples were prepared from the fifteen rams and each sample was assayed in triplicate The numbers of copies were determined using the following formula (Liu et al., 2012):

6 statistical analysis

Amount of DNA $(\mu \mathrm{g} / \mathrm{mL}) \times 6.022 \times 10^{23}$

Length $(b p) \times 10^{9} \times 650$

For all analyses SPSS 22.00 software (Armonk, NY: IBM Corp.) was used. Effective ruminal degradation (ERD $\mathrm{NFD}$ ) and disappearance rates of NFD were calculated as previously described. We used One-Way (ANOVA) to investigate the effect of different diet treatment groups (independent variable), rumen fermentation criteria and rumen micro-organisms community. To investigate the effect of time (within-subject 
factor) and group (betweensubject factor) and time $\mathrm{X}$ group interaction on the intra-rumen degradation of NFD kinetics we used, mixed analys is of variance
(Mixed ANOVA. Duncan's post-hoc test was used where appropriate. Differences were declared significant at $P \leq 0.05$.

Table (1) Basal diet ingredients and its chemical composition

\begin{tabular}{|c|c|}
\hline \multicolumn{2}{|l|}{ Ingredient (g/kg fed basis) } \\
\hline Wheat bran, sorghum straw, grains, and corn stalk & 347.838g \\
\hline Soybean meal & $226.744 \mathrm{~g}$ \\
\hline Wheat skin & $174.4185 \mathrm{~g}$ \\
\hline Sorghum, oats, millet, and corn & $62.5 \mathrm{~g}$ each \\
\hline Sheep mineral mix ture & $1 \mathrm{gm}$ \\
\hline \multicolumn{2}{|l|}{ Mineral-Vitamin block } \\
\hline Salt $(\mathrm{NaCl})$ & $14-16 \%$ \\
\hline Calcium (Ca) & $23.5-28 \%$ \\
\hline Phosphorous & (P) $6.6 \%$ \\
\hline Copper $(\mathbf{C u})$ & $13-24$ ppm \\
\hline Zinc (Zn) & $2500 \mathrm{ppm}$ \\
\hline Vitamin A (IU) & 350,000 \\
\hline Vitamin D3(IU) & 250,000 \\
\hline Vitamin E (IU) & 300 \\
\hline \multicolumn{2}{|l|}{ Chemical composition g/kg } \\
\hline Dry matter & 575 \\
\hline Crude protein & 104 \\
\hline Organic matter & 941.7 \\
\hline Ash & 58.3 \\
\hline NDF & 102 \\
\hline
\end{tabular}

Table (2) Rumen microbial primer sequences used for PCR and qPCR assay.

\begin{tabular}{|c|c|c|c|}
\hline \multicolumn{2}{|c|}{$\begin{array}{c}\text { Primer sequence } \\
\text { (forward/reverse) }\end{array}$} & $\begin{array}{c}\text { Amplicon } \\
\text { length (bp) }\end{array}$ & Reference \\
\hline Total bacteria & F: CGGCAACGAGCGCAACCC & 130 & $\begin{array}{c}\text { Denman and } \\
\text { McSweeney, } \\
2006\end{array}$ \\
\hline & R: CCATTGTAGCACGTGTAGCC & & \\
\hline Methanogens & F: GGATTAGATACCCSGGTAGT & 191 & $\begin{array}{c}\text { Zhang et al., } \\
2008\end{array}$ \\
\hline & R: GTTGARTCCAATTAAACCGCA & & 121 \\
\hline F.succinogenes & F:GTTCGGAATTACTGGGCGTAAA & $\begin{array}{c}\text { Koike and } \\
\text { Kobayashi, } \\
2001\end{array}$ \\
\hline & R: CGCCTGCCCCTGAACTATC & & $\begin{array}{c}\text { Sylvester et } \\
\text { al., 2004 }\end{array}$ \\
\hline Protozoas & F: GCTTTCGWTGGTAGTGTATT & 223 & \\
\hline & R:CTTGCCCTCYAATCGTWCT & & \\
\hline
\end{tabular}




\section{Results}

1. Intra-rumen degradation of

Neutral Detergent Fiber (NFD)

kinetics

There was a significant effect of different diet groups on the effective ruminal degradation (ERD\%) | of NDF at $24 \mathrm{hrs}$ groups $(P \leq 0.05)$ (Table 3$)$. The degradable fraction $\mathrm{B}$ was significantly greater in $\mathrm{PF}$ group, while the control group (CONT) showed the lowest degradable $\mathrm{B}$ fraction and lowest ERD NDF recorded in CONT group (Figure1-A). Concurrently with there was a significant increase of the undegradable $\mathrm{C}$ fraction of the control group and it was the lowest in PF group $(P \leq 0.05)$. Time, diet treatment and time $\times$ group interaction significantly influenced the disappearance\% of NDF during 24hrs. The NDF disappearance \% was significantly changed from $1.20 \%$ at 2 hrs. to $46.48 \%$ at 24 hrs $\left(P \leq 0.05, \eta^{2}=0.99\right)$. And as mentioned previously the greatest disappearance $\%$ was recorded in the PF group while the lowest was found in the CONT group $\quad(P<0.001$, $\eta^{2}=0.79$ ) (Table 3). Finally, the time $\times$ group interaction showed that the greatest disappearance\% of NDF was found at $24 \mathrm{hrs}$ in PF group (52.88 \pm 0.41$)$ while the lowest disappearance \% was measured at $2 \mathrm{hrs}$ in the G3 group $(0.35 \pm 0.04) \quad(P \leq 0.05$, $\eta^{2}=0.62$ ). (Figure 1-B).

Results for rumen $\mathrm{pH}$ and ammonia-N were not significantly $(P>0.05)$ affected by diet| treatments among groups, whereas the total VFA were significantly greater $(P<0.05)$ in G3 group and significantly lowered in HT group (Table 4). The molar proportions of isovalerate propionate and isobutyrate did not significantly change $(P>0.05)$ between the different treatment groups. However, the molar proportions of acetate and valerate were significantly $(P<0.05)$ reduced in HT group. Butyrate were significantly $(P<0.05)$ increased in control group. The acetate propionate ration (A: P) ratio was not affected by any of the diet groups $(P>0.05)$ (Table 4).

4. Rumen micro-organisms

\section{community}

The quantity of the rumen microbes showed a significant $(\mathrm{P} \leq 0.05)$ increase in the total protozoa population in G9 and PF groups and decreases HT and G3 groups (Table 4). Methanogens were significantly $(\mathrm{P} \leq 0.05)$ increased in $\mathrm{G} 9$ group and significantly reduced in $\mathrm{PF}$ groups $(\mathrm{P} \leq 0.05)$. Total bacteria and $F$. succinogenes populations were not affected by any of diet treatment groups (Table 5). 
Table (3) In situ ruminal Neutral Detergent Fiber (NFD) kinetic

\begin{tabular}{|c|c|c|c|c|c|c|}
\hline & \multicolumn{5}{|c|}{ Treatment group } & \\
\hline Parameters & CONT & HT & $\mathbf{P F}$ & G3 & G9 & $P$-value \\
\hline В \% & $84.15 \pm 0.95^{c}$ & $85.20 \pm 1.91^{c}$ & $93.76 \pm 0.72^{\mathrm{a}}$ & $88.19 \pm 2.32^{b c}$ & $90.78 \pm 1.90^{\mathrm{ab}}$ & 0.004 \\
\hline $\mathrm{C} \%$ & $15.49 \pm 0.95^{a}$ & $14.80 \pm 1.91^{a}$ & $6.24 \pm 0.72^{c}$ & $11.81 \pm 2.32^{\mathrm{ab}}$ & $9.22 \pm 1.90^{\mathrm{bc}}$ & 0.004 \\
\hline $\operatorname{kdB}\left(\% h^{-1}\right)$ & $2.63^{\mathrm{e}}$ & $3.08^{c}$ & $3.46^{b}$ & $3.51^{\mathrm{a}}$ & $2.70^{d}$ & $P<0.001$ \\
\hline ERD \% & $81.48 \pm 1.40^{c}$ & $83.57 \pm 1.87^{\text {bc }}$ & $92.16 \pm 0.71^{\mathrm{a}}$ & $85.71 \pm 2.51^{\text {bc }}$ & $88.80 \pm 1.85^{\mathrm{ab}}$ & 0.001 \\
\hline $\begin{array}{l}\text { Disappearance } \\
\%\end{array}$ & $39.73 \pm 0.55^{c}$ & $44.64 \pm 1.35^{b}$ & $52.88 \pm 0.41^{\mathrm{a}}$ & $50.18 \pm 1.32^{\mathrm{a}}$ & $44.98 \pm 0.53^{b}$ & $P<0.001$ \\
\hline
\end{tabular}

degradation in different diet groups at $24 \mathrm{~h}$.

Means within a row with different superscriptletters differ $(P \leq 0.05)$.

$B \%=$ degradable $N D F$ fraction, $C \%=$ undegradable $N D F$ fraction, $k d B=$ The degradation rate of degradable $B$ fraction, CONT = control group, $H T=$ Hydrolyzable tannin group, $P F=$ Pueraria flavone group, $G 3=$ Gannon No.3 group and $G 9=$ Gannon No.9 group.
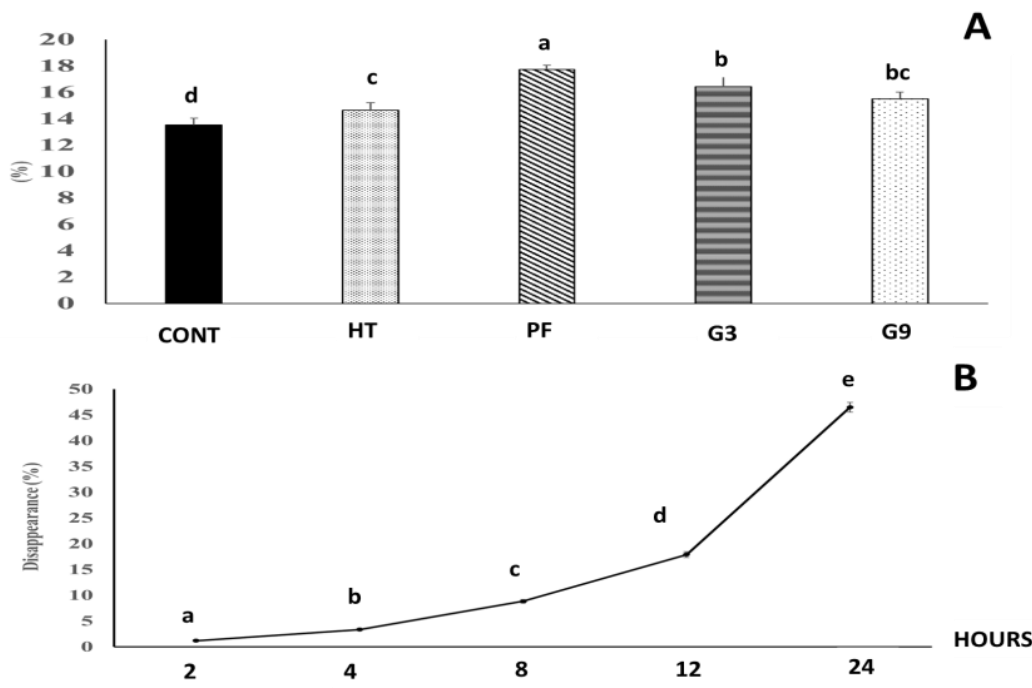

Figure (1) Disappearance (\%) of NDF during 24 hours in different time points $(A)$ and different treatment groups $(B)$.

3 Rumen fermentation parameters 
Table (4) Ruminal fermentation criteria in different diet groups.

\begin{tabular}{|c|c|c|c|c|c|c|}
\hline & \multicolumn{5}{|c|}{ Treatment group } & \multirow[b]{2}{*}{$\begin{array}{c}P- \\
\text { value }\end{array}$} \\
\hline Parameters & CONT & HT & PF & G3 & G9 & \\
\hline PH & $6.25 \pm 0.09$ & $6.44 \pm 0.16$ & $6.41 \pm 0.05$ & $6.37 \pm 0.05$ & $6.31 \pm 0.05$ & 0.62 \\
\hline Ammonia-N & $15.27 \pm 3.12$ & $15.81 \pm 2.01$ & $20.09 \pm 1.99$ & $22.50 \pm 2.48$ & $19.28 \pm 2.23$ & 0.25 \\
\hline TVFA & $115.78 \pm 2.81^{\mathrm{a}}$ & $90.50 \pm 6.68^{c}$ & $102.02 \pm 4.41^{\mathrm{ab}}$ & $120.41 \pm 6.30^{\mathrm{a}}$ & $97.73 \pm 6.23^{\mathrm{bc}}$ & 0.016 \\
\hline Isovalerate & $1.40 \pm 0.37$ & $0.71 \pm 0.07$ & $0.68 \pm 0.10$ & $1.16 \pm 0.23$ & $1.19 \pm 0.10$ & 0.12 \\
\hline Propionate & $24.31 \pm 1.60$ & $23.23 \pm 1.98$ & $21.51 \pm 1.01$ & $27.12 \pm 1.34$ & $20.27 \pm 1.95$ & 0.094 \\
\hline Isobutyrate & $0.85 \pm 0.14$ & $0.56 \pm 0.06$ & $0.61 \pm 0.02$ & $0.81 \pm 0.08$ & $0.86 \pm 0.04$ & 0.06 \\
\hline Acetate & $73.22 \pm 1.77^{a}$ & $55.86 \pm 5.10^{b}$ & $67.86 \pm 3.52^{\mathrm{ab}}$ & $76.91 \pm 3.85^{a}$ & $64.57 \pm 4.68^{a b}$ & 0.03 \\
\hline Butyrate & $14.38 \pm 0.68^{\mathrm{a}}$ & $9.34 \pm 0.97^{b}$ & $10.30 \pm 0.17^{b}$ & $12.71 \pm 2.01^{\mathrm{ab}}$ & $9.27 \pm 0.86^{b}$ & 0.03 \\
\hline Valerate & $1.62 \pm 0.25^{\mathrm{ab}}$ & $0.79 \pm 0.06^{c}$ & $1.06 \pm 0.09^{\mathrm{bc}}$ & $1.71 \pm 0.27^{\mathrm{a}}$ & $1.56 \pm 0.06^{a b}$ & 0.01 \\
\hline $\begin{array}{l}\text { Acetate/Propionate } \\
\text { ratio }\end{array}$ & $3.05 \pm 0.26$ & $2.43 \pm 0.29$ & $3.15 \pm 0.02$ & $2.85 \pm 0.21$ & $3.22 \pm 0.21$ & 0.16 \\
\hline
\end{tabular}

Means within a row with different superscript letters differ $(P \leq 0.05)$.

CONT = control group, HT = Hydrolyzable tannin group, $P F=$ Pueraria flavone group, G3 = Gannon No. 3 group and G9= Gannon No.9 group.

Table (5) Effect of feeding different diets on rumen microbial population (copies $/ \mathrm{mL}$ ) in different diet groups

\begin{tabular}{|c|c|c|c|c|c|c|}
\hline & \multicolumn{5}{|c|}{ Treatment group } & \multirow[b]{2}{*}{$P$-value } \\
\hline Parameters & CONT & HT & PF & G3 & G9 & \\
\hline $\begin{array}{l}\text { Total bacteria } \\
\left(\times 10^{15}\right)\end{array}$ & $5.60 \pm 3.59$ & $2.82 \pm 0.02$ & $10.71 \pm 10.0$ & $0.66 \pm 0.38$ & $5.78 \pm 0.45$ & 0.23 \\
\hline $\begin{array}{l}\text { F.succinogenes } \\
\left(\times 10^{12}\right)\end{array}$ & $7.44 \pm 1.22$ & $8.46 \pm 5.30$ & $5.17 \pm 0.77$ & $5.72 \pm 0.68$ & $10.19 \pm 7.88$ & $\overline{0.81}$ \\
\hline $\begin{array}{l}\text { Methanogens } \\
\left(\times 10^{13}\right)\end{array}$ & $2.09 \pm 0.34^{b}$ & $1.56 \pm 0.39^{b}$ & $0.83 \pm 0.02^{c}$ & $1.57 \pm 067^{b}$ & $4.28 \pm 1.20^{\mathrm{a}}$ & 0.036 \\
\hline Protozoas $\left(\times 10^{12}\right)$ & $2.88 \pm 1.30^{\mathrm{ab}}$ & $1.61 \pm 1.00^{b}$ & $6.01 \pm 5.90^{a}$ & $1.36 \pm 0.23^{b}$ & $6.95 \pm 2.40^{\mathrm{a}}$ & 0.039 \\
\hline
\end{tabular}

\section{Dis cussion}

In the current study we found some interesting results of the effect of some PSM used as feed additives versus feeding the whole plants of alfalfa and their effect on the rumen fermentation of sheep.
Rumen

fermentation

parameters, NDF digestion and rumen microbial population results are related to each other, therefore we must discuss them altogether. Rumen $\mathrm{pH}$ is the balance between TVFA and ammonia, and it is produced by 
rumen microorganisms. In the current study, rumen $\mathrm{pH}$ and ammonia did not significantly change between different groups; meanwhile, TVFA were significantly reduced in HT group because of the significant proportional reduction in acetate and valerate acids, similar to Bhatta et al. (2009) and Gemeda and Hassen (2015) in their study about the effect of phenolic compounds and tannin on rumen fermentation, tannin had decreased the TVFA production in the rumen which is attributed to the anti-microbial effect of tannin. In fact, several studies referred to the selective inhibitory effect of tannins to microbial growth, the gallotannins which is the type fed to the HT group strongly inhibited the cellulolytic activity of bacteria (Tagari et al., 1965) these cellulolytic bacteria which digest fibers and produce VFA (Birgitte et al., 2018). Also, we find that G3 group results showed increased TVFA although alfalfa Gannon No.3 contains higher levels of tannin (Mohamaden et al., 2020), which supports the theory that different source $s$ of tannins provides different effects.

Addition of Flavonoids or tannic acids to diet decrease the degradation (Oskoueian et al., 2013) or may have no significant effect on NDF or other chemical metabolites
(Aguiar et al., 2014). Paula et al. (2016) and Zhan et al. (2017) found that the NDF degradation tended to increase with increasing flavonoid supplementation to cows' diet. Our study recorded that addition of fla vonoids to diet significantly increased the NDF ruminal effective degradation due to the increased $B$ degradable fraction and significant decrease in the $\mathrm{C}$ undegradable fraction, we attribute the results of NDF the significant increase in the total protozoal population, according to (Bera-Maillet et al., 2005) who suggested the rumen ciliated protozoa have a high fibrolytic capacity. Also, total bacteria showed non- significant increase in the total bacteria quatitiaive PCR, and even though the $F$. succinogenes were not significantly changed, other unmeasured cellulolytic bacteria would be increased in population such as $R$. albus and B. fibrisolvens. Ma et al. 2016 recorded a significant increase in the digestibility of NDF in the mulberry leaf flavonoid supplemented sheep. Nevertheless, G9 alfalfa variety contains higher levels of total flavonoid compared to G3 alfalfa variety (Mohamaden et al., 2020). G9 and PF groups favored the growth ruminal protozoal, meanwhile, HT and G3 groups showed a significant 
decrease in the protozoa population due to the antiprotozoal effect of tannin (Animut et al., 2008 and Hristov et al., 2013). In fact, the increase in the total protozoa enhances the methanogens growth (Newbold et al., 2015) as they symbiotically live on external surface of the protozoa (Morgavi et al., 2014 and Belanche et al., 2014). Meanwhile, other researchers found that adding different types of flavonoids to rumen fluid would suppress the population of almost rumen microorganisms generally and specific types of flavonoids as naringin and quercetin could decrease the population of total protozoa and methanogens especially in Oskoueian et al. (2013). However, these studies were conducted in vitro which follow restricted experimental factors and only focusing on their specific types of microorganisms, while the rumen encloses billions of microbes live under anaerobic conditions which still cannot be cultured and still influencing rumen fermentation and digestion in the presence or absence of PSM and these ruminal microbes deserve further investigation.

\section{Conclusion}

Usage of PSM as feed additives could produce different effects on rumen ecosystem and in turn, it would affect the different management feeding according to the purposes of animal breeding. Hydrolysable tannin proved to reduce the TVFA production and protozoal population which would decrease the protein utilization by ruminants and that is important in improving the fattening farms. Pueraria flavone and Gannon No.9 alfalfa variety favored the growth of protozoa which in turn enhanced the digestion of NDF. Feeding ewes on Gannon No. 3 alfalfa variety would increase the milk production due to its favorable effect by increases the TVFA.

\section{Acknowledgement}

The current study was supported by the Integration and Demonstration of Key Technologies for Ecological

Animal Husbandry in the Qinghai-Tibet Plateau (Gannan Community) (Grant No. 201203010).

\section{References}

Aguiar, S.C.; Paula, E.M., Yoshimura, E.H., et al. (2014). Effects of phenolic compounds in propolis on digestive and ruminal parameters in dairy cows. Rev. Bras. Zoo. Tec. 43, 197-206.
Alhidary, I. A., Abdelrahman, M. M., Alyemni, A. H., Khan, R. U., Al-Saiady, M. Y., 
Amran, R. A., \& Alshamiry, F. A. (2016). Effect of alfalfa hay on growth performance, carcass characteristics, and meat quality of growing lambs with ad libitum access to total mixed rations. Revista Brasileira de Zootecnia, 45, 302-308.

Animut, G., Puchala, R., Goetsch, A. L, Patra, A. K. Sahlu, T., Varel, V. H., and Wells, J. (2008). Methane emission by goats consuming different sources of condensed tannins. Anim. Feed. Sci. Technol. 144, 228-241.

Belanche, A., de la Fuente. G., Ne wbold, C.J. (2014). Study of methanogen communities associated with different rumen protozoal populations. FEMS Microbiol Ecol. 90, 663-77.

Bera-Maillet, C., Devillard, E., Cezette, M., Jouany, J. P., and Forano, E. (2005). Xylanases and carboxymethylcellulases of the rumen protozoa Polyplastron multivesiculatum, Eudiplodinium maggii and Entodinium sp. FEMS Microbiol. Lett. 244, 149-156. doi:

10.1016/j.femsle.2005.01.035

Bhatta R, Uyeno $Y$, Tajima $K$, Takenaka A, Yabumoto Y, Nonaka I, Enishi O, Kurihara M. (2009). Difference in the nature of tannins on in vitro ruminal methane and volatile fatty acid production and on methanogenic archaea and protozoal populations. J. Dairy Sci. 92, 5512-5522.

Birgitte, K. A., Nanditha, M., Kee rthi, S. (2018). Fermentation of Cellulose with a Mixed Microbial Rumen Culture with and without Methanogenesis. J. Ferment. Technol. 07. 10.4172/21677972.1000152.

Bodas, R., Prieto, N., GarcíaGonzález, R. Andrés , S., Giráldez, F.J., López, S. (2012). Manipulation of rumen fermentation and methane production with plant secondary metabolites. Anim. Feed Sci. Technol .176, 78-93.

Burt, S. (2004). Essential oils: their antibacterial properties and potential applications in foodsa review. Int. J. Food Microbiol. 94, 223-253

Faichney, G.J., Graham, N.M., Walker, D.M. (1999). Rumen characteristics, methane emissions, and digestion in weaned lambs reared in isolation. Aust J Agric Res. 50, 1083-90.

Gemeda, B. S. and Hassen A. (2015). Effect of tannin and species variation on in vitro digestibility, gas, and methane production of tropical browse plants. Asian Australas. J. Anim. Sci. 28, 188-199. 
Hristov, A. N., C. Oh, J Lee, R. Meinen, F. Montes, T. Ott, J. Firkins, A. Rotz, C. Dell, A. Adesogan, W. Yang, J. Tricarico, E. Kebreab, G. Waghorn, J. Dijkstra, and S. Oosting. (2013). Mitigation of greenhouse gas emissions in livestock production - A review of technical options for non$\mathrm{CO} 2$ emissions. FAO Animal Production and Health Paper No. 177 (Ed. P. J. Gerber, B. Henderson, and H. P. S. Makkar). FAO, Rome, Italy.

Kamra D.N., Pawar M., Singh B. (2012). Effect of Plant Secondary Metabolites on Rumen Methanogens and Methane Emissions by Ruminants. In: Patra A. (eds) Dietary Phytochemicals and Microbes. Springer, Dordrecht.

Li, Z., Q. Deng, et al. (2018). Dynamics of methanogenesis, ruminal fermentation and fiber digestibility in ruminants following elimination of protozoa: a meta-analysis. J. Anim. Sci Biotechno. 9, 89.

Liu, Y., Xu, Z.-q., Zhang, Q., Jin, M., Yu, J.-m., Li, J.-s., Duan, Z.-j. (2012). Simultaneous detection of seven enteric viruses associated with acute gastroenteritis by a multiplexed Luminex-based assay. Journal of clinical microbiology, 50(7), 2384-2389. doi: $10.1128 / j \mathrm{~cm} .06790-11$
Machmuller, A., Soliva, C. R., Kreuzer, R. (2003). Effect of coconut oil and defaunation treatment on methanogenes is in sheep. Reprod. Nutr. Dev. 43, 41-55.

McCann, J. C., Wickersham, T. A., et al. (2014). "Highthroughput Methods Redefine the Rumen Microbiome and Its Relationship with Nutrition and Metabolism. Bioinform. Biol. Insights 8, 109-125.

Ma T, Chen DD, Tu Y, Zhang NF, Si B W, Diao QY. (2017). Dietary supplementation with mulberry leaf flavonoids inhibits methanogenesis in sheep. Anim Sci J. Jan;88(1):72-78. doi: 10.1111/asj.12556. Epub 2016 Apr 25. PMID: 27112278

Mats ui, M., H. Wada, et al. (1992). "Gas-chromatographic determination of volatile fatty acids in aqueous samples by direct injection." Journal of Environmental Chemistry 2: 211-216.

McMahon, L. R., T. A. McAllister, et al. (2000). A review of the effects of forage condensed tannins on ruminal fermentation and bloat in grazing cattle. Can. J. Plant Sci. $80,469-485$.

McSweeney, C., Palmer B., et al. (2001). Microbial interactions with tannins: 
Nutritional consequences for ruminants. Anim. Feed Sci. Technol. 91, 83-93.

Mohamaden W.I., Hegab I.M. Hui C., Shi S.L. (2020). In situ ruminal degradation kinetics, blood metabolites, and weight gain as an effect of feeding different sources of tannin and flavonoids to small-tailed Han rams. Livestock journal. In press.

Morgavi, D.P., Forano, E., Martin, C. (2010). Newbold CJ. Microbial ecosystem and methanogenes is in ruminants. Animal. 4, 1024-36.

Mosoni, P., Martin, C., Forano, E., Morgavi, D.P. (2011). Long-term defaunation increases the abundance of cellulolytic ruminococci and methanogens but does not affect the bacterial and methanogen diversity in the rumen of sheep. J. Anim. Sci. 89, 783-91.

Newbold, C. J., G. de la Fuente, et al. (2015). The Role of Ciliate Protozoa in the Rumen. Frontiers in Microbiology 6,1313 .

Ørskov, E., McDonald, I. (1979). The estimation of protein degradability in the rumen from incubation measurements weighted according to rate of passage. $\mathrm{J}$. Agric. Sci.". 92, 499-503.
Oskoueian, E., Norhani, A., Oskoueian, A. (2013). Effects of flavonoids on rumen fermentation activity, methane production, and microbial population. BioMed Research International. 349129.

Paula, E.M., Samensari, R.B., Machado, E., Pereira, L.M., Maia, F.J. (2016). Effects of phenolic compounds on ruminal protozoa population, ruminal fermentation, and digestion in water buffaloes. Livest Sci. 185, 136-41.

Peng, K., D. Shirley, et al. (2016). Effect of purple prairie clover (Dalea purpurea Vent.) hay and its condensed tannins on growth performance, wool growth, nutrient digestibility, blood metabolites and ruminal fermentation in lambs fed total mixed rations. Anim. Feed Sci. Technol. 222, 100-110.

Tagari, H., Heins, Y., Tamir, M., Volcani, R. (1965). Effect of carob pod extract on cellulolysis, proteolysis, deamination, and protein biosynthesis in an artificial rumen. Appl. Microbiol. 13, 437-442.

Tan, H. Y., Sieo, C. C. et al. (2011). Effects of condensed tannins from Leucaena on methane production, rumen fermentation and populations of methanogens and protozoa in 
vitro. Anim. Feed Sci. Technol. 169, 185-193.

Van Soest P.J., Robertson, J.B., Lewis, B.A. (1991). Methods for dietary fiber, neutral detergent fiber and nonstarch polysaccharides in relation to animal nutrition. $J$. Dairy Sci. 74, $3583-3597$.

Weatherburn, M. W. (1967). Phenol-hypochlorite reaction for determination of ammonia. Anal. Chem. 39, 971-974.

Williams A. G., Coleman G. S. (1992). The Rumen Protozoa. 1st ed. New York: SpringerVerlag.

Yáñez-Ruiz, D. R., Hart, K. J., Martin-Garcia, A. I., Belanche
A., Newbold C. J. (2007). The effect of absence of protozoa on methane emissions by lambs in Proceedings of the British Society of Animal Science, Penicuik, p. 47.

Yu Z. and Morrison $M$. (2004). Improved extraction of PCR-quality community DNA from digesta and fecal samples. Biotechniques 36: 808-812.

Zhan, J., M. Liu, et al. (2017). Effects of alfalfa flavonoids on the production performance, immune system, and ruminal fermentation of dairy cows. Asian-Australas J. Anim. Sci. 30, 1416-1424.

تأثير التانين والفلافونيدات من مصادر مختلفة على تخمر الكرش والتجمعات

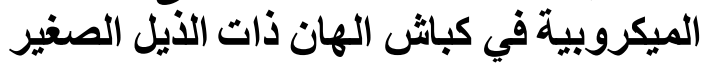

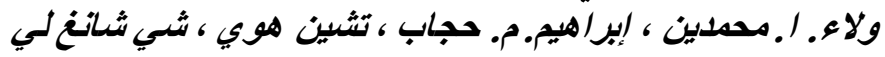

تم استخدام المستقلبات الثانوية النباتية (PSM) كاضافات أعلاف للمانشية بدلاً من المواد

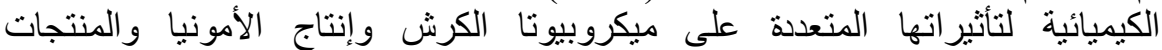

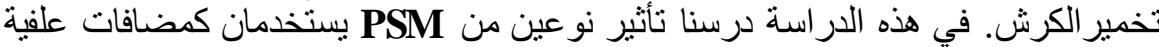

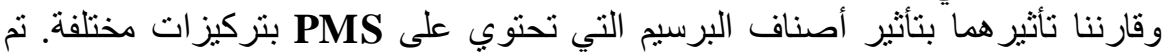

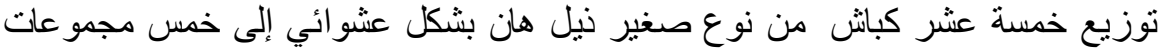

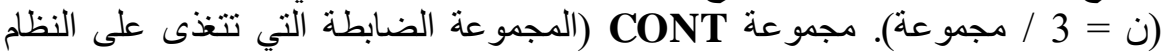

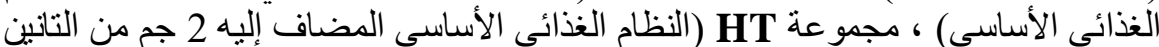

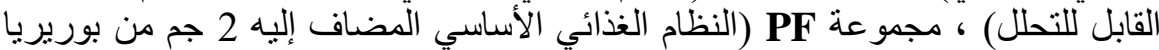

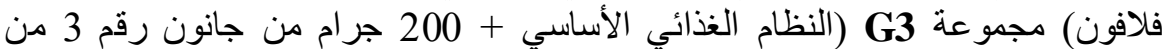

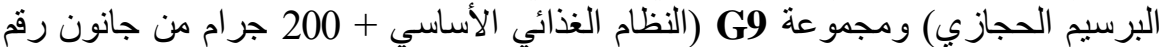

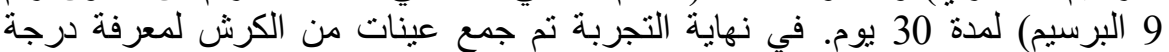

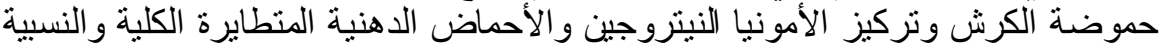

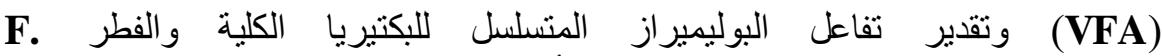
succinogenase 
في الموقع لفول الصويا NDF. أظهرت النتائج أن درجة حموضة الكرش وأمونيا

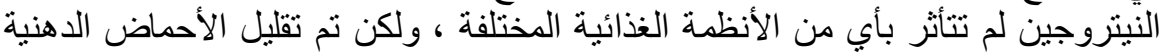

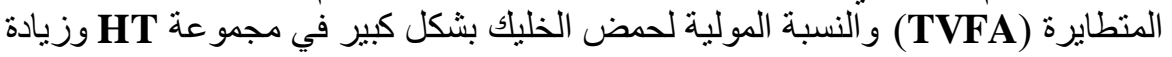

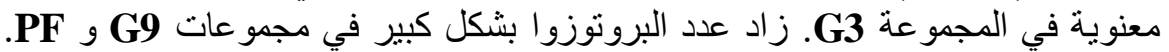

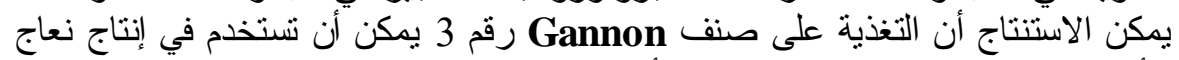

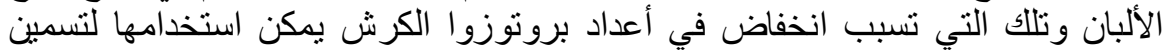
الكباش يمكن استخدام إضافات الأعلاف وأنواع مختلفة من البرسيم في إدارات التئل التغنية المختلفة للحصول على أقصى إنتاج الأعلات 